\title{
鼣 \\ DINAMIKA PEMIKIRAN DAN GERAKAN POLITIK NAHDLATUL ULAMA
}

\author{
Firdaus Muhammad \\ IAIN Raden Intan Lampung \\ Firdaus.muh@yahoo.com
}

\begin{abstract}
Abstrak
Tulisan ini menyoroti dinamika politik Nahdlatul Ulama dalam perspektif sosiologis, historis, dan antropologis. Berdasarkan kenyataan yang ada, dinamika politik NU nampaknya telah merambah pada berbagai aspek, meliputi aspek keagamaan, politik, dan budaya. $\mathrm{NU}$ pernah terlibat dalam dunia politik. Organisasi ini pernah juga menyatakan keluar dari dunia politik Kemampuan NU dalam beradaptasi dengan perkembangan dan tuntutan zaman telah membuat organisasi ini tetap eksis di tengah arus perubahan politik masyarakat dan menjadi suatu organisasi keagamaan terbesar di Indonesia.
\end{abstract}

\begin{abstract}
This paper highlights the political dynamics of The Nahdlatul Ulama in sociological, historical and anthropological perspectives. Based on the facts, the political dynamics of $\mathrm{NU}$ has served on a variety of aspects, including religious, political, and cultural. NU ever involved in politics. It also ever declared itself out of the political world. The ability of NU to adapt the development and the demands of the times has made this organization still exists in the current political changes in the society and become the largest religious organization in Indonesia.
\end{abstract}

Kata Kunci: Pemikiran, Gerakan, Nahdlatul Ulama

\section{A. Pendahuluan}

Nahdlatul Ulama (NU) merupakan organisasi politik keagamaan yang tidak dapat dipisahkan dengan tradisi dunia 
pesantren, yang mana yang menjadikan ketokohan kiai sebagai figur sentral. Kharisma kiai cukup mewarnai dinamika sejarah perjalanan politik NU, bahkan NU identik dengan ulama-ulama kharismatik yang cukup berpengaruh. Pada hakikatnya NU merupakan manifestasi modern daripada kehidupan keagamaan, politik budaya para kiai. Corak gerakan NU oleh pengamat dianggap sebagai organisasi yang mewakili sayap tradisionalis sebagai antitesis dari kelompok modernis seperti Muhammadiyah. ${ }^{1}$

Dalam sejarahnya, NU berdiri sebagai bentuk reaksi dari luar terhadap gerakan pemurnian dan pembaharuan yang dilakukan oleh kelompok modernis (Muhammadiyah dan Persis). Berdirinya organisasi ini tidak terlepas dari peran kiai dengan komunitas utama di pesantren dan masyarakat pedesaan yang menjadi peyangga utama kelompok Islam tradisional ini. Dengan demikian, sifat keberadaan NU merupakan upaya peneguhan kembali nilainilai tradisi-tradisi politik keagamaan yang telah melembaga dalam jaringan struktur dan pola hidup yang lebih mapan meliputi: Lembaga pesantren, kiai, santri dan jama'ah. Mereka tersebar di tanah air sebagai unit-unit komunitas politik budaya masyarakat Islam sehingga NU tidak kesulitan di dalam mengembangkan organisasinya. Fenomena ini tercermin pada pengaruh Hadratus Syekh KH. Hasyim Asyari' di seluruh pesantren se-Jawa melalui jaringan geneologis keilmuan yang lebih kuat, sehingga ketika NU pertama kali politikisasikan mendapat dukungan dan simpati dari kiai dan masyarakat pesantren pada umumnya dan kontribusinya dalam membangun tradisi keilmuan melalui basis kiai-pesantren. ${ }^{2}$

Tradisi keilmuan yang dianut NU bersandar pada doktrin Aswaja yang berpangkal pada tiga panutan inti: Pertama tauhid dengan mengikuti faham Asyari dan Maturidi. Kedua, dalam bidang fiqih mengikuti salah satu dari empat imam mashab. Ketiga, dalam bidang Tasawuf (tarekat) mengikuti cara Junaid al-Baghdadi dan Imam al-Ghazali. Hal tersebut menjadi landasan kesunnian NU dalam mengembangkan tradisi keilmuan agama yang paripurna. ${ }^{3}$

${ }^{1}$ Deliar Noer, Partai di Pentas Politik Nasional 1945-1965, (Jakarta: Pustaka Utama Grafiti, 1987), h. 49.

${ }^{2}$ Zamakhsyari Dhofier, Tradisi Pesantren: Studi tentang Pandangan Hidup Kiai, (Jakarta: LP3ES, 1983), h. 79.

${ }^{3}$ Abdurrahman Wahid, Mengurai Hubungan Agama dan Negara, (Jakarta: 
Inti tradisi keilmuan yang dianut NU berpautan organis antara tauhid, fiqih dan tasawuf secara berkesinambungan, yang dalamjangka panjang menumbuhkan pandangan terpautnya antara dimensi duniawi dan ukhrawi dalam kehidupan. Selain menjaga kontinuitas tradisi keilmuan NU, aspek lain yang cukup menonjol adalah pada pengembangan basis yang berakar pada pesantren dan tarekat. Basis riil NU adalah lembaga-lembaga pesantren dan kiai. Namun Martin Van Bruinessen mengkhawatirkan sekiranya dalam satu pondok tidak ada yang dapat diharapkan menjadi penerusnya, maka dalam jangka waktu tertentu hal ini menjadi penyebab runtuhnya ideologi pesantren yang mendasarkan kharisma dari jalur keturunan ${ }^{4}$.

NU kemudian berkiprah secara kongkrit setelah terjun dalam kancah kehidupan berbangsa dan bernegara, khususnya dalam bidang politik keagamaan, politik budaya dan politik. Untuk itu klaim NU sebagai organisasi tradisisional mulai berubah, bahkan mengalami pergeseran drastis. Nakamura menyatakan bahwa klaim NU sebagai organisasi tradisional dalam perkembangannya tidak lagi identik dengan konservatisme, kaum sarungan yang membawakan kepada kejumudan, dekadensi dan kebekuan, para pengikutnya tidak lagi dianggap sebagai penghambat kemajuan. ${ }^{5}$

Fenomena tersebut antara lain mulai tampak sejak awal tahun1980-an, terutamadalamerakepemimpinan KH.Abdurrahman Wahid selama lima belas tahun menakhodai NU selaku ketua umum PBNU. Ia cukup berhasil meletakkan dasar-dasar pemikiran progresif, modern dan inklusif. Meskipun demikian, corak dan warna ketradisionalannya tetap dipertahankan berdasarkan pada kaidah:“ Al-Mukhafazatuh alal Qadimis Shalih wa Akhzu Aslahah". Mengambil nilai-nilai baru yang lebih baik dan mempertahankan nilai-nilai lama yang masih relevan".

Grasindo: 1999), h. 323.

${ }^{4}$ Martin Van Bruinessen, NU: Tradisi, Relasi-relasi Kuasa, Pencarian Wacana Baru,(Yogya: LkiS,1995), h. 153.

5 Mitsio Nakamura, " Tradisionalisme Radikal: Catatan Muktamar Semarang 1979”, dalam Greg Fealy dan Greg Barton, Nahdlatul Ulama, Traditional Islam and Modernity in Indonesia, Terj. Ahmad Suedi (dkk), Tradisionalisme Radikal: Persinggungan Nahdlatul Ulama - Negara, (Yogyakarta: LKiS, 1997), h. 58. 
Mengamati fenomena tersebut, Nakamura menyatakan adanya indikator ke arah NU progresif, yakni sebuah fenomena baru NU yang mencerminkan kiprahnya menjadi kaum tradisionalis yang radikal, sulit diingkari bahwa NU telah menunjukkan langkah yang semakin radikal tentu dalam pengertian luas. ${ }^{6}$

Fenomena menarik lainnya adalah keterlibatan NU secara langsung dalam memberdayakan Civil Society melalui gerakan politik dan kultural NU. Mengamati fenomena kiprah NU dijalur kultural ini, maka peran dan kiprah kaum muda NU tidak dapat disangsikan keberadaanya. Beberapa di anatara tokoh muda NU eksis di jalur kultural dan memilih pada pengembangan pemikiran dan gerakan politik, seperti pemberdayaan anak jalanan. ${ }^{7}$

Transformasi politik yang mewarnai dinamika perjalanan NU ini difokuskan pada aspek sosiologis atau sosio-hostoris yang mengiringi dinamika politik NU, baik internal (organisasi NU) maupun eksternal (negara). Untuk menyoroti perjalanan sejarah politik NU secara utuh, totalitas dan universal. Fenomena ini menarik karena NU dalam kurun waktu cukup panjang antar generasi yang memiliki karakter dan tipologi yang berbeda dalam mewarnai NU, mereka eksis melakukan gerakan politik di segala bidang di tengah-tengah perubahan politik.

Berbagai kajian yang dilakukan pengamat NU dan akademisi itu mengindikasikan bahwa, NU menarik dikaji dari berbagai aspek penelitian. Berdasarkan pada beberapa hasil penelitian tentang NU, baik berupa tulisan lepas (opini), skripsi, tesis maupun disertasi. Namun nampaknya dari berbagai hasil penelitian yang ada, belum ditemukan sebuah penelitian yang secara fokus mengkaji proses transformasi gerakan politik keagamaan NU berdasarkan pada sejarah politik NU secara komprehensif yang menunjukkan terjadinya pergeseran paradigma gerakan NU, dari gerakan politik keagamaan, kiprahnya dalam politik praktis, pergulatan wacana pemikiran hingga memberdayakan masyarakat sipil (civil society), yakni mengkaji gerakan dan pemikiran NU tentang Civil Society dan implementasinya.

${ }^{6}$ Ibid, h. 61.

${ }^{7}$ Hairus Salim, M.Ridwan, Kultur Hibrida: Anak Muda NU di Jalur Kultural, (Yogyakarta: LkiS, 1999), h. 1-18; bandingkan dengan Muh. Siddiq, Gejolak Santri Kota yang memotret kiprah angkatan muda NU khususnya di LKiS. 
Untuk itu, penulis mencoba mengkaji proses transformasi politik keagamaan yang mewarnai dinamika perjalanan politik NU. Disamping adanya pergeseran paradigma gerakan politik keagamaan NU sebagai wacana rekonstruksi wacana tradisionalis menjadi tradisionalisme radikal bahkan telah merambah dalam wacana post-tradisionalis.

Wajah NU belakangan kian berubah sesuai proses yang dilaluinya beserta kondisi politik yang mewarnai dinamika NU, baik secara intern maupun ekstern. Upaya rekonstruksi wacana tradisionalis NU tampak pada wacana yang dikembangkan generasi belakangan, dan kini telah merambah wacana liberalisme bahkan menuju post liberalis yang menampilkan wajah baru NU yang ditampilkan kaum muda NU yang eksis di jalur kultural.

Pelacakan sejarah politik dan proses transformasi, basis gerakan politik serta pemikiran dalam NU tentang pemberdayaan civil society pasca Khittah 1926, berikut dikemukakan beberapa alasan meliputi:

Pertama, Nahdlatul Ulama yang sejak berdiri merupakan organisasi politik keagamaan yang menjadikan figur kiai menjadi penyanggah utama dengan berbasis pada pesantren (kiai-santri). Sepanjang sejarahnya NU mengalami proses transformasi yang mewarnai dinamika perjalanannya, di mana NU sejak awal berdirinya diklaim sebagai kelompok tradisionalis kini merambah dalam kancah kehidupan yang lebih terbuka di samping lahirnya sarjana-sarjana NU yang telah bersentuhan wacana modernitas dan komunitas akademis. Hal itu merupakan fenomena baru dalam organisasi keagamaan ini.

Kedua, NU yang menjadikan kiai sebagai figur sentral juga telah mengalami banyak perubahan atau pergeseran, di samping karena kiai itu sendiri mulai terbuka terhadap nilai-nilai baru. Bahkan telah bersentuhan secara intensif dengan politik termasuk politik praktis, fenomena ini misalnya tampak ketika NU menjadi partai politik tahun 1950-an dan belakangan dalam era reformasi, pentolan NU seperti KH.Abdurrahman Wahid terpilih menjadi presiden keempat, KH. Kholil Bisri menjadi Wakil ketua MPR dan beberapa kiai yang aktif dalam PKB dan partai berbasis NU lainnya menggiring beberapa kiai menjadi anggota legislatif. Meskipun 
demikian, sebagian besar ulama NU tetap memilih berkiprah secara penuh dengan membina pondok pesantren masing-masing.

Ketiga, Langkah-langkah progresif dan aksi atau gerakan politik kaum muda NUyang eksis dijalur kultural menjadi fenomena menarik, khususnya dalam membangun proyek pemberdayaan civil society. Kiprah kaum muda NU di jalur kultural ini menjadi bagian proses transformasi yang menunjukkan bahwa NU kini dan ke depan semakin eksis dengan mengadopsi perkembangan yang terjadi dalam berbagai aspeknya. Kelompok kaum muda NU pada dasarnya juga terbagi dua, yakni sekelompok berkiprah di pentas politik nasional seperti Muhaimin Iskandar, Efendi Choiri, Masykur Musa, Khofifah Indar Parawansa dan lainnya. Kelompok kedua adalah mereka yang eksis pada jalur kultural seperti Ulil Abhsar Abdalla, Ahmad Baso, Rumadi, Zuhairi Misrawi dll, mereka memilih berkiprah di jalur kultural dengan mengembangkan nalar kritis wacana pemikiran keagamaan dan gerakan politik menuju pada pemberdayaan Civil Society.

Dalam masing-masing priode ini, mengindikasikan bahwa NU mengalami proses transformasi dari dominasi kiai ke priode sarjana (intelektual) dan belakangan kaum muda mengambil peran yang kontribusinya cukup diperhitungan. Proses yang menunjukkan dinamika dan proses kreatif masing-masing generasi dalam merespon berbagai perkembangan kontemporer, misalnya melalui lembaga Bahtsul Masail. Lembaga yang berbasis ulama ini secara intensif membahas masalah politik (fiqih siyasah) dalam masalah agama tematik (diniyah maudhuiyah) meliputi masalah bernegara, demokratisasi, demokrasi, demontrasi, HAM dan reksadana. Masalah tersebut biasanya dibicarakan dalam munas atau muktamar yang membahas masalah agama sehari-hari (diniyah waqiiyah) seperti shalat jum'at dua angkatan, nikah mut'ah, nikah di bawah tangan dan di bawah umur, hak atas tanah, insulin, kloning, demonstrasi dan unjuk rasa. Hal ini mengindikasikan betapa ulama NU cukup progresif dalam merespon berbagai masalah politik kemasyarakatan. Kemudian kiprah kaum intelektual berhasil mengangkat wajah NU dalam pentas nasional dan international seperti yang diperankan KH. Abdurrahman Wahid dan KH. Hasyim Muzadi. Peran lain yang cukup diperhitungkan adalah eksisnya 
kaum muda NU di jalur kultural dengan obsesi memberdayakan masyarakat sipil (civil society) berupa pembelaan hak buruh dan petani miskin di desa-desa terpencil.

Dalam kancah perpolitikan nasional, kemampuan NU dalam mengambil peran dengan negara (NU Vis a Vis Negara). Pada kondisi tertentu, NU sangat fleksibel dan akomodatif dengan pemerintah (negara), namun pada kondisi lain NU menjadi oposan terhadap kebijakan politik pemerintah (negara). ${ }^{8}$ Dalam hal ini para pengamat asing dan akademisi menjadi daya tarik tersendiri untuk dikaji sesuai disiplin ilmu masing-masing, baik kalangan sosiolog maupun pengamat politik keagamaan dan pengamat asing seperti Nakamura, Andree Fillard, Greg Barton Martin Van Bruinessen, Sidney Jones dan lainnya.

Sementara pada dekade terakhir terjadi pergeseran gerakan politik kegamaan NU terus menunjukkan nuansa dinamika merupakan fenomena yang perlu dicermati secara akdemis, misalnya pergulatan kelompok politisi dan intelektual-akademisi serta yang aktif dalam gerakan budaya atau gerakan kultur masingmasing berkiprah dalam konteks politik dan politik di tanah air. Berbagai dinamika yang mewarnai perjalanan NU tersebut menarik dibaca terutama pada kesiapan NU menerima nilai-nilai baru dengan tetap mempertahankan nilai lama yang masih relevan.

Dalam kerangka pikir ini, penulis kemudian berasumsi bahwa fenomena tersebut sebagai proses transformasi politik dalam pengertian lebih global, yakni transformasi politik keagamaan, politik, budaya. Hal ini pulalah yang mewarnai gerakan politik kultural dan transformatif NU sepanjang sejarah.

Kemudian mengulas mengenai proses transformasi politik dalam pemikiran kaum NU yang mewarnai dinamika perjalanan politik NU di tengah-tengah arus perubahan politik dengan menumbuhkan sikap keterbukaannya terhadap nilainilai modernitas dalam setiap dimensi kehidupan, termasuk dalam kancah kehidupan politik, budaya, agama, berbangsa dan bernegara.

${ }^{8}$ Andree Fillard, NU Vis a Vis Negara: Pencarian Isi, Bentuk dan Makna, (Yogyakarta: LkiS, 1999), h. 13. 
Kemudian kajian ini juga mencoba menguak komitmen dan kiprah NU dalam memberdayakan Civil Society sebagai aplikasi gerakan politik-kulturalnya, kaitannya dengan implementasi khittah NU 1926 sejak tahun 1984 untuk memberdayakan kaum Nahdliyin yang merupakan agenda obsesif kaum muda NU yang concern di jalur kultural, di samping pengembangan nalar kritis wacana pemikiran sebagai pijakan menuju post-tradisionalisme Islam dan Liberalisme pemikiran Islam sebagai kontribusi dalam dalam pergulatan wacana pemikiran di tanah air.

Dari rentetan persoalan tersebut tampaknya dapat teridentifkasibahwa pergeseran paradigmagerakan politikNUtidak terlepas dari sosio-kultural dan kondisi politik yang mengiringi proses terjadinya transformasi politik dalam sejarah politik NU. Dengan adanya sikap keterbukaan kaum NU terhadap nilai-nilai modernitas serta lahirnya sarjana-sarjana NU cukup berpengaruh terhadap dinamika perkembangan NU. Meskipun demikian, keberadaan kiai-kiai di pesantren tetap menjadi penyanggah utama sebagai basis politik NU yang tetap dipertahankan dan diberdayakan. Proses tersebut berlangsung melalui komitmen untuk pengembangan dan pemberdayaan umat setelah melalui proses yang cukup panjang yang kelak melahirkan generasi dari kiai-intelektual. Dalam konteks ini, NU relevan dianalisis melalui kekayaan khasanah dan nilai-nilai tradisi yang dianutnya, sehingga dalam perjalananya selalu dinamis. Proses transformasi politik yang mewarnai perjalanan politik NU dalam menyikapi berbagai perubahan baik secara internal maupun eksternal.

Transformasi politik yang mengiringi gerakan kaum muda NU, mereka concern di jalur kultural dan berkiprah dengan mengusung wacana pemikiran dan gerakan-gerakan politik yang mengarah pada pemberdayaan Civil Society dan penguatan gerakan politik keagamaan dalam NU antara lain, SDM NU semakin meningkat ditandai lahirnya para sarjana-sarjana yang memiliki latar belakang NU yang cukup kental, di samping proses kreatif kaum muda NU yang berkiprah di jalur kultural. Mereka sangat peka-sensitif terhadap berbagai wacana yang berkembang serta kontribusinya dalam mengembangkan dan memberdayakan Civil Society patut diperhitungkan. 
Berdasarkan pada uraian di atas, transformasi yang terjadi dalam tubuh organisasi keagamaan NU yang secara khusus mengkaji mengenai proses transformasi gerakan politik kaum muda NU sebagai objek kajian ini. Transformasi dalam konteks ini difahami sebagai sebuah proses perubahan bentuk dari institusiinstitusi yang pernah dimunculkannya, atau setidaknya yang mewarnai proses transformasi gerakan politik tersebut. Proses transformasi tersebut dalam beberapa kasus hanya terjadi pada level strategi taktik, tanpa melibatkan basis massa dan ideologinya. Akan tetapi pada kasus yang berbeda justru melibatkan masingmasing variabel tersebut.

Gerakan politik dalam NU memang pada awalnya terkesan bersifat reaktif yang dipengaruhi adanya kondisi sosio piolitik di satu sisi dan faktor eksternal yang menggiring lahirnya proses perubahan itu. Karena itu, penulis melihat konteks gerakan yang menjadi objek kajian dalam penelitian mengenai gerakan politik NU ini bahwa, transformasi tersebut terjadi dalam beberapa bentuk meliputi; pertama, tumbuhnya kesadaran kaum muda NU secara kolektif setelah bersentuhan dengan lingkup kehidupan real di masyarakat, di samping adanya pengaruh nuansa dan aura akademik bagi mereka yang melanjutkan pendidikan pasca pesantren. Periodeisasi yang menandai transformasi ini teridentifikasi sejak awal tahun 1980-an tepatnya pasca NU kembali ke Khittah 1926 dan fenomena ini berkesinambungan hingga sekarang. Meskipun demikian, melihat interval waktu yang mengiringi proses transformasi gerakan politik kaum muda NU adalah lahirnya intelektual muda NU yang dipelopori oleh kehadiran KH. Abdurrahman Wahid (Gus Dur) yang sekaligus sebagai lokomotif intelektualisme NU yang baru pulang belajar di Timur Tengah. Kedua, transformasi dari sebuah gerakan politik sekaligus kultural yang menjadi basis utama gerakan kaum muda NU tersebut menjadi gerakan transformatif di tingkat generasi muda khususnya yang aktif di kampus (baca: mahasiswa). Basis gerakan mereka dibangun melalui lembaga kajian dan politik yang kelak menelorkan LKiS di Yogyakarta, Piramida Circle, Lakpesdam , P3M masing-masing di Jakarta dan beberapa organisasi kaum muda NU yang secara geneologis berakar pada "ideologi” NU. Aktivitas mereka cukup beragam mulai dari tataran mengusung wacana 
termasuk dalam membangun Jaringan Islam liberal (JIL) yang cukup fenomenal hingga merambah pada gerakan-gerakan politik seperti pemberdayaan Civil Society.

Tentu proses transformasi tersebut mengindikasikan terjadinya pergeseran paradigma gerakan politik keagamaan NU. Mengingat bahwa hal itu tidak hanya terjadi pada hal-hal yang profan saja, melainkan menyentuh pula pada aspek-aspek yang sacred (sakral) dari sebuah gerakan. Secara sederhana, proses transformasi yang terjadi itu berawal dari visi transformatif agama yang menjafdi spirit dan sumber nilai gerakan.

\section{B. Transformasi Paradigma Politik NU}

Dalam menjelaskan perilaku politik NU harus berangkat dari peran NU di awal negeri ini sedang mencari formulasi pasca proklamasi 1945, menyusul pertikaian partai-partai politik yang kian memanas misalnya pertentangan antara partai Islam tentang dasar negara dengan nasionalis sekuler. Kemudian pertentangan NU dengan Masyumi yang berakhir pada langkah NU menjadi partai politik melalui muktamar NU ke 17 di Palembang 1952. Demikian pula, NU vis a vis negara, terpentalnya para politisi NU di PPP hingga berakhir pada keputusan kembali ke khittan 1926. Belum tuntas pembicaraan tentang khittah yang masih multiinterpretatif dikalangan intern NU sendiri, tiba-tiba rezim Orde Baru tumbang sehingga hasrat para kiai-politisi NU membentuk PKB tidak dapat dibendung.

Sepanjang perjalanan sejarah NU itulah, jika dibaca secara pintas maka tidak heran jika dikesankan penuh dengan kontroversikontroversi dan ketidakkonsistenan dalam sikap politiknya. Dalam perspektif ini, Syamsul Ma'arif tampaknya benar. Tapi apakah tidak lebih tepatjika dibaca sebagai dinamika dibanding kontroversi.Lebih dari itu juga wajar jika ia menaruh harapan dalam melihat prospek politik NU ke depan dengan berbagai tawaran yang diasumsikan dapat menyelamatkan kendaraan politik NU untuk tidak tergilas dengan lawan-lawan politiknya. Tapi yang harus dicatat, NU bukan partai politik - pasca khittah - sehingga kaum nahdliyin bebas memilih partai yang diinginkan. Sebaliknya, kaum nahdliyin justru diintai banyak partai. Dalam hal ini elit NU diharapkan mampu 
memberi pendidikan politik bagi kaum nahdliyin agar selektif memilih partai yakni, bukan emotional choice tapi rational choice.

Namun jika kita mencoba melacak proses transformasi yang mengiringi perjalanan NU sepanjang sejarahnya yang terus mengalami pergeseran, maka harus dilihat latar belakang dan setting politik setiap keputusan yang diambil elite politik dan kiai khos NU. Dalam hal ini, penulis berusaha mengurai bentangan sejarah NU melalui tiga periodesasi sehingga tampak jelas adanya transformasi paradigma politik NU dan polarisasi gerakan masingmasing periode. Disamping mengklarifikasi stigma kontroversi untuk dibaca sebagai dinamika. Artinya, riak-riak intern NU merupakan dinamika yang justru membuat NU lebih dinamis dan eksis.

Pertama, periode reaktif-defensif (1926-1952), periode ini lebih menonjolkan peran kiai atau dominasi kiai. Tipologi gerakannya lebih concern pada gerakan politik keagamaan. NU lebih reaktif-defensif menghadapi kelompok modernis dengan gerakan pembaharuan-pemurniannya yang vis a vis dengan kelompok tradisional (NU). Kedua merupakan periode defensif-politis (19521984). Dalam periode ini, elit NU melakukan "ijtihad politik" untuk terjun ke politik praktis dan NU dijadikan partai politik setelah memisahkan diri dari Masyumi (1952). Partai NU berhasil menempati urutan ketiga pada pemilu 1955 dibawah PNI dan Masyumi. Pergulatan NU dalam kancah politik mengantarkan kaderkadernya seperti KH.Wahid Hasyim dan KH.Saefuddin Zuhri sebagai menteri agama yang "menguntungkan" dalam melegitimasi faham keagamaannya. Tetapi jika kita jujur melihat sejarah, sepanjang periode ini kegiatan politik keagamaan NU lebih terbengkalai. Di tangan para politisi NU lebih banyak menggiring massa NU secara emosional ke kancah politik praktis yang tidak jarang melahirkan dinamika internal dalam tubuh NU sendiri.

Periode ketiga (1984-sekarang). Tipologi gerakan NU mulai bergeser dari orientasi politik kembali pada garis perjuangannya melalui keputusan kembali ke khittah 1926 pada muktamar NU ke27 di Situbondo 1984. Periode kiai-intelektual ini berhasil menaikkan daya tawar NU. Selama dua periode sebelumnya, NU terkesan belum diperhitungkan, meski turut berkeringat dalam 
membangun bangsa ini, tetapi nyaris tidak pernah mencicipi kue kekuasaan, terkecuali posisi menteri agama. Fenomena lain dari periode ini adalah tampilnya anak-anak muda NU yang eksis di jalur kultural, mereka kreatif mengusung ide-ide kritis melalui berbagai wacana liberalisasi pemikiran kaum muda NU diantaranya, teologi pembebasan, Islam Kiri hingga Post-Tradisionalis Islam. Disamping lahirnya sarjana-sarjana NU yang bergulat dalam dunia akademis dan birokrat. NU pada periode ini tidak dapat dikatakan kelompok tradisionalis lagi tapi post-tradisionalis.

Berangkat dari satu periode ke periode berikutnya, gerakan NU senantiasa mengalami pergeseran, baik sikap maupun paradigma gerakannya meliputi; gerakan politik keagamaan, politik dan kultural serta gerakan pemikiran yang condong progresifliberal. Hal itu justru membuat NU semakin eksis dan dinamis.

Pergeseran paradigma gerakan NU tersebut menunjukkan kedewasaan elit NU dalam mengadaptasi setiap perubahan, baik dalam tataran pemikiran, politik keagamaan dan politik. Paradigma politik NU bergeser total pasca kembali ke khittah 1926, yakni, pergeseran perilaku politik NU dari politik praktis ke politik moral kebangsaan.

Gerakan-gerakan NU mengalami pergeseran dari dominasi kiai, kiai-politisi hingga kiai-intelektual. Wajah NU pasca kembali ke khittah 1926 dan NU pasca Gus Dur. Tampaknya berbeda dengan masa NU sebagai partai politik, kini NU berusaha menunjukkan identitasnya sebagai organisasi politik keagamaan an sich, serta berusaha mengambil garis demarkasi antara NU dan PKB- partai bentukan PBNU periode Gus Dur. Sikap NU itu juga mempengaruhi perilaku politiknya, NU mencoba meminimalisir konflik dan dinamika internalnya.

Mengamati periode KH.Hasyim Muzadi terdapat adanya transformasi sikap politik NU yang jelas sebagai implementasi khittah NU 1926, yakni NU tidak memainkan politik praktis demi kepentingan kekuasaan, tetapi NU harus memainkan politik moral-kebangsaan. Artinya jika ada suatu hal yang membahayakan kelangsungan hidup bernegara, maka NU harus turun tangan seperti menyikapi isu terorisme, radikalisme agama. Jika demikian, maka kesan perilaku politik NU yang sesak dengan kontroversi 
menjadi tidak relevan. Harapan Syamsul Ma'arif pada NU untuk menghentikan kebiasaan berkontroversi juga menjadi utopis, jika kontroversi yang dimaksud adalah perbedaan pandangan di intern NU. Sebab telah menjadi "tradisi" di NU perbedaan pandangan (politik) itu sebagai implikasi fleksibilitas dalam memahami fikih politiknya. Tetapi sebesar apapun konflik atau perseteruan itu menjadi sirna setelah dilakukan islah (rekonsiliasi) internal.

Sementara harapan untuk menata-ulang atau memperbaharui hubungan NU dengan kelompok modernis juga nihil, apalagi jika belajar dari kejatuhan Gus Dur. Poros tengah yang didominasi kelompok modernis yang semula mendukung, dalam waktu cukup singkat terjadi pembelotan hingga berhasil menggulingkan Gus Dur yang sebelumnya dieluk-elukkan. Sebab itu sulit untuk meyakinkan kaum nahdliyin untuk berkoalisi dengan kelompok modernis. Apalagi jika merunut ke belakang, jatuh bangun NU dan pil pahit marginalisasi NU dalam kancah politik tidak terlepas dari perlakuan kelompok modernis, baik di Masyumi atau pada Poros Tengah. Selanjutnya, keinginan agar NU mengambil garis demarkasi dengan partai yang ada, penulis kira tepat, sebab NU adalah aset bangsa yang harus diberdayakan. Demikian juga upaya untuk meningkatkan kualitas SDM kaum nahdliyin. Kita juga sepakat dengan Syamsul Ma'arif bahwa urusan politikNU ke depan diserahkan pada kader-kadernya tanpa menyeret NU ke kancah politik praktis. Sebab kader-kader muda NU mulai menunjukkan eksistensinya, sebagian memilih pada jalur politikstruktural dan lainnya di jalur kultural. Kaum muda NU jalur kultural ini merupakan aset yang cukup potensial memajukan NU. Mereka cukup concern melakukan kerja-kerja politik seperti pendampingan anak jalanan, pendidikan politik, pemberdayaan tani buruh. Di pundak mereka NU dapat membangun kemandirian masyarakat sekaligus menjadi pioner penguatan civil society pasca Gus Dur menegara. Lengsernya Gus Dur dari kursi kekuasaan justru merupakan kemenangan NU kultural.

Langkah NU mengembangkan paradigma baru politik moral-kebangsaan untuk menjaga keutuhan bangsa cukup bijak, sebagai implementasi khittah NU 1926 dengan membentangkan garis demarkasi antara gerakan kultural NU dengan politik praktis. 
Upaya NU untuk memberdayakan masyarakat melalui jalur kultural ini didedikasikan sebagai penguatan civil society, sehingga NU baik sebagai jam'iyah (organisasi) maupun jama'ah (komunitas) turut menciptakan negara-bangsa yang kondusif, lebih religius, damai dan demokratis.

Adapun garis-garis besar dan ide dasar perjuangan NU, dirumuskan sebagai khittah Nahdlatul Ulama, Muktamar NU telah merumuskan defenisi bahwa:

1. Khittah Nahdlatul Ulama adalah landasan berfikir, bersikap dan bertindak warga Nahdlatul Ulama yang harus dicerminkan dalam tingkah laku perseorangan maupun organisasi dan dalam setiap proses pengambilan keputusan.

2. Landasan tersebut dalam paham Ahlussunah wal-Jama'ah yang ditetapkan menurut kondisi kemasyarakatan di Indonesia, meliputi dasar-dasar keagamaan maupun kemasyarakatan.

3. Khittah Nahdlatul Ulama juga digali dari rintisan perjalanan sejarah kehidmatannya dari masa ke masa. ${ }^{9}$

Meskipun telah melalui proses panjang, keputusan muktamar NU ke-27, yang resmi meninggalkan arena politik praktis atau kembali ke khittah 1926, ternyata masih menemui kendala, karena masih banyak kalangan NU yang secara tegas atau diamdiam tidak menyetujuinya.

Kembalinya NU ke khittah dan menjadi organisasi politikkeagamaan bukan hanya demi memenuhi tuntutan politik pada masa itu, tetapi juga sebuah kesadaran konkret bahwa NU semenjak lahir 1926, pada dasarnya adalah organisasi yang bergerak di bidang agama, politik, dakwah dan pendidikan. Dengan kembalinya NU menjadi organisasi politik keagamaan, para kiai dan elite NU dapat memfokuskan tenaga dan pikirannya untuk pengembangan dan pemberdayaan umat melalui program yang dipersiapkan secara matang dan meliputi bidang yang cukup luas. Dalam hal ini, NU diasumsikan telah kembali beralih orientasi dari kancah dunia politik praktis menjadi politik praktis, dari prestise politik menjadi prestise keagamaan dalam masyarakat. Bahrul Ulum menjadikan

${ }^{9}$ Ibid, h. 92. 
sikap tawazzun (seimbang), tawassuth (tengah), i'tidal (lurus), tasamuh (toleran) dan amar makrufnahi mungkar, yang dijabarkan dari doktrin (ahlussunnah wal-jamah). Dengan sikap tersebut, NU akan tampil ke depan sebagai figur panutan bagi semua kalangan. ${ }^{10}$

Sementara itu, pertautan Civil Society dan Penguatan Khittah NU 1926 dikaji dengan melihat adanya perbenturan wacana yang senantiasa mewarnai letupan-letupan wacana yang digagas pemikir Islam untuk mencari formulasi Islam keindonesiaan sebagai pengukuhan kesadaran identitas dalam wacana civil society, yakni mengadopsi istilah ini dari berbagai sumber untuk dipertemukan dengan kekayaan tradisi Islam keindonesiaan.

Berdasarkan pada bukti sejarah perpolitikan di Indonesia, era awal pemerintahan Orde Baru menunjukkan bahwa kebijakan restrukturisasi politiknya telah melemahkan kekuatan politik formal Islam, sebaliknya justru memberi peluang tumbuhnya kekuatan informal Islam. Dalam kondisi ini, As'ad menganalisinya sebagai fenomena baru yang menunjukkan beberapa kebijakan yang lebih mengarah pada penguatan posisi negara, dan sedikit sekali yang mengarah pada penguatan posisi masyarakat. Implikassinya, keterlibatan pemerintah dalam pengendalian kekuatan-kekuatan yang ada dalam masyarakat, termasuk kekuatan-kekuatan yang bermotif keagamaan, sulit terhindarkan. ${ }^{11}$ Sementara Dawam Rahardjo melihat kondisi ini, khususnya bagi kalangan intelektual muslim akan berdampak buruk bagi proses demokratisasi, di era 1990-an kaum intelektual mulai mengembangkan wacana civil society atau masyarakat madani sebagai refleksi frustasi masyarakat terhadap proses demokratisasi yang kemudian diartikulasikan sebagai bentuk perlawanan yang mengarah pada penguatan civil society. ${ }^{12}$

10 Sikap akomodatif NU senantiasa dipengaruhi atas kaidah tersebut sehingga NU dapat meminimalisir gerakan radikal massanya, seperti menjelang saat pelengseran Abdurrahman Wahid dari kursi kepresidenan dan hal itu tidak terlepas dari sikap para kiai yang menjadi panutan dan tokoh sentral dalam NU yang mampu menenangkan massa NU. Sikap kiai tersebut membuktikan kuatnya pengaruh sikap akomodatifnya melalui sikap toleran tersebut.

${ }^{11}$ As'ad, Teologi Humanistik: Kajian tentang Wacana Islam Pembebas di Kalangan Pemikir Muslim Indonesia Masa Orde Baru, (Surabaya: Tesis PPs Sunan Ampel, 2001), h. 74 .

${ }^{12}$ M. Dawam Rahardjo, Masyarakat Madani: Agama, Kelas Menengah dan 
Lemahnya kekuatan civil society ini di hadapan negara menjadi preseden buruk bagi proses demokratisasi itu sendiri. Implikasinya bagi organisasi Islam yang diharapkan memberi kontribusi dalam memperkuat civil society, justru tidak terlibat dalam proses transformasi, NU misalnya belum mengalami proses transformasi secara memadai dalam visi politiknya dalam mengantisipasi perubahan politik. Selain itu, mereka juga belum mampu mentransformasikan diri sebagai entitas yang memberi nuansa penguatan terhadap civil society ketika berhadapan dengan kekuasaan negara. Dalam kerangka pikir ini, Abdurrahman Wahid menghendaki organisasi Islam seperti NU untuk mengubah orientasinya pada penguatan civil society. ${ }^{13}$

Di kalangan intelektual Islam Indonesia memperebutkan wacanaini untukdiklaim sebagai representasigerakan keagamaanya yang sarat muatan politis dan ideologis.Tidak heran kemudian, jika seorang AS.Hikam selalu mengklaim NU sebagai civil society karena dianggapnya memiliki kedekataan antara konsep civil society dengan tradisi yang dianut NU, bahkan khittah NU dibaca sebagai wujud gerakan kultural sebagai bagian pemberdayaan civil society. ${ }^{14}$

Kesadaran tersebut semakin diperkokoh dengan munculnya analisis-analisis sejumlah sarjana dan pengamat yang mengidentikkan NU sebagai gerakan pro-civil society, seperti yang dilakukan oleh Douglas E. Remage ${ }^{15}$ dan Dhaniel Dhakidae ${ }^{16}$ yang menyebut NU sebagai the last bastion of civil society di Indonesia. Demikian pula dalam tulisan Fajrul Falakh mencoba

Perubahan Politik, (Jakarta: LP3ES, 1999), h. 241.

${ }^{13}$ Abdurrahman Wahid, "Islam dan Pemberdayaan Civil Society", seperti dikutip AS Hikam, "Wacana Intelektual tentang Civil Society di Indonesia”, dalam Paramadina Vol.1, No.2 (1999), h. 43-44.

${ }^{14}$ Muhammad AS.Hikam, "Khittah dan Penguatan Civil Society di Indonesia: Sebuah kajian Historis Struktural atas NU sejak 1984”, dalam Ellayasa KH. Dharwis, Gus Dur, NU dan Masyarakat Sipil, (Yogyakarta: LKiS, 1997), h. 133-163.

${ }^{15}$ Lihat, Douglas E. Remage, “ Democration, Religios Tolerance, and Pancasila: The Political Thought of Abdurrahman Wahid”, dalam Greg Barton dan Greg Fealy (eds.). Nahdlatul Ulama, Traditional Islam, and Modernity in Indonesia (Clayton: Monash Asia Institute, 1996), h. 254 dan 227.

16 Lihat tulisan Dhaniel Dhakidae, "Langkah Non-Politik dari Politik Nahdlatul Ulama”, dalam Ellayasa KH. Dharwis (ed), Gus Dur, NU dan Masyarakat Sipil, (Yogyakarta: LKiS, 1997), h. 125-131. 
menghubungkan NU dengan cita-cita masyarakat Madani. Falaakh memperkuat tesis itu dengan merujuk pada hasil-hasil muktamar NU di Situbondo dan Cipasung dengan membaca khittah NU sebagai cita-cita politik NU. Dalam tulisan tersebut, ia menegaskan civil society sebagai cita-cita politik NU. Dan iapun mengeritik analisis Kuntowijoyo, Kenneth Ward, dan Ben Anderson yang masing-masing menyebut NU sebagai kawula, oportunis dan akomodasionis dan bahkan NU dicap hanya lebih tertarik pada isu atau persoalan yang sepenuhnya religius dan meraih sukses besar dalam mempertahankan jati dirinya. ${ }^{17}$

Mempertautkan antara civil society dengan gerakan politik NU sebagai upaya penguatan khittah NU merupakan langkah antisipatif dalam merancang kembali cita-cita NU. Dalam hal ini, Muhammad Fajrul Falaakh mengemukakan mengenai cita-cita politik NU dengan didasarkan pada hasil rumusan muktamar NU sejak tahun 1984 di Situbondo yang cukup monumental, yakni mengembalikan NU kepada khittah 1926 sebagai organisasi politik keagamaan, sebagaimana cita-cita NU sejak awal. Tentu dengan penafsirannnya sendiri terhadap khittah 1926, Falaakh mencoba menyesuaikannya dengan cita-cita masyarakat madani. Ia menyebut empat sikap kemasyarakatan NU (al-tawasuth wa ali'tidal, tasamuh, tawasun dan amar ma'ruf nahi mungkar) sebagai representasi sikap politik NU. Sikap politik NU tersebut senantiasa mewarnai dan mempengaruhi aktivitas politiknya, misalnya dalam merealisasikan konsepsi amar ma'ruf nahi mungkar sebagai wujud tanggung jawabnya dengan penuh kesadaran.

Berdasarkan padanilai-nilaiiniNUmengembangkangerakan politik keagamaan NU, artinya nilai tersebut diinternalisasikan

${ }_{17}$ Mohammad Fajrul Falaakh, "NU dan Cita-Cita Masyarakat madani", Pikiran rakyat, 1 Februari 1996, dan Mohammad Fajrul Falaakh, "Pemberdayaan Masyarakat madani dalam NU”, Makalah Lokakarya Penyusunan Program Lakpesdam NU 1996-2001, PKBI, Jakarta, 15 Juli 1996. Sementara tulisan pemikir yang dikritik Falaakh ini, misalnya Kuntowijoyo dalam, Paradigma Islam: Interpretasi untuk Aksi, ( Bandung: Mizan, 1996), h. 226-227, dan untuk Kenneth E Ward, "The 1971 Election in Indonesia”, (Clayton: Monash University, 1974) dan Ben Anderson, "Religion and Politics in Indonesia since Independence", dalam Religion and Social Ethos in Indonesia (Clayton: Monash University, 1997). 
dalam gerakan politik keagamaan (gerakan dakwah kultural) NU, termasuk dalam upaya penguatan civil society itu sendiri.

\section{Penutup}

Proses transformasi gerakan politik keagamaan NU secara keseluruhan tidak terlepas dari bentangan sejarahnya yang cukup panjang lebih dari 70 tahun. Secara periodik dibagi ke dalam tiga periode yakni: pertama, periode kiai dan pesantren (19261952), kedua periode Kiai-Politisi (1952-1984) dan ketiga Periode kiai-intelektual (1984-sekarang). Pembagian tiga periode tersebut tidak dapat dipahami secara kaku, tetapi harus dilihat secara proporsional sesuai dinamika perjalanan politik NU sejak berdiri hingga sekarang sesuai dengan setting politik yang melahirkan kontekstualisasi gerakan yang fleksibel. []

\section{Daftar Pustaka}

As'ad, Teologi Humanistik :Kajian tentang Wacana Islam Pembebas di Kalangan Pemikir Muslim Indonesia Masa Orde Baru, Surabaya: Tesis PPs Sunan Ampel, 2001.

Bruinessen, Martin Van , NU :Tradisi, Relasi-relasi Kuasa,Pencarian Wacana Baru, Yogyakarta : LKiS,1995.

Dhakidae, Dhaniel, "Langkah Non-Politik dari Politik Nahdlatul Ulama”, dalam Ellayasa KH. Dharwis (ed), Gus Dur, NU dan Masyarakat Sipil, Yogyakarta: LKiS, 1997.

Dhofier, Zamakhsyari, Tradisi Pesantren: Studi tentang Pandangan Hidup Kiai, Jakarta: LP3ES, 1983.

Fillard, Andree, NU Vis a Vis Negara: Pencarian Isi, Bentuk dan Makna, Yogyakarta: LKiS, 1999.

Falaakh, Mohammad Fajrul, "NU dan Cita-Cita Masyarakat madani”, Pikiran Rakyat, 1 Februari 1996.

- - "Pemberdayaan Masyarakat madani dalam NU", Makalah Lokakarya Penyusunan Program Lakpesdam NU 1996-2001, PKBI, Jakarta, 15 Juli 1996. 
Noer, Deliar,. Partai di Pentas Politik Nasional 1945-1965, Jakarta: Pustaka Utama Grafiti, 1987.

Wahid, Abdurrahman, Mengurai Hubungan Agama dan Negara, Jakarta: Grasindo: 1999.

Nakamura, Mitsio, "Tradisionalisme Radikal: Catatan Muktamar Semarang, 1979”, Dalam Greg Fealy dan Greg Barton, Nahdlatul Ulama, Traditional Islam and Modernity in Indonesia, Terj.AhmadSuedi(dkk),TradisionalismeRadikal:Persinggungan Nahdlatul Ulama - Negara, Yogyakarta: LKiS, 1997.

Salim, Hairus, M.Ridwan, Kultur Hibrida : Anak Muda NU di Jalur Kultural, Yogyakarta: LKiS: 1999.

Siddiq, Muh. Gejolak Santri Kota yang memotret kiprah angkatan muda NU, Yogyakarta: Tiara wacana: 2001.

Rahardjo, M. Dawam, Masyarakat Madani: Agama, Kelas Menengah dan Perubahan Politik, Jakarta: LP3ES, 1999.

Hikam, AS "Wacana Intelektual tentang Civil Society di Indonesia”, dalam Paramadina Vol.1, No.2 1999.

__-, "Khittah dan Penguatan Civil Society di Indonesia: Sebuah Kajian Historis Struktural atas NU sejak 1984", dalam Ellayasa KH. Dharwis, Gus Dur, NU dan Masyarakat Sipil, Yogyakarta: LKiS, 1997.

Remage, Douglas E. “ Democration, Religios Tolerance, and Pancasila: The Political Thought of Abdurrahman Wahid", dalam Greg Barton dan

Greg Fealy, (ed), Nahdlatul Ulama, Traditional Islam, and Modernity in Indonesia, Clayton: Monash Asia Institute, 1996. 
Firdaus Muhammad 